\title{
Effect of Direct Instructional Model, Problem Solving, and Attitude on Lay Up Shoot Learning Outcomes in Basketball Games
}

\author{
Janner Sanjaya ${ }^{1}$ \\ \{*sanjayajanner@gmail.com \} \\ Department of Physical Education, Universitas Negeri Medan, Medan, Indonesia ${ }^{1}$
}

\begin{abstract}
The research was carried out Private Vocational High School (SMK) Raksana 2 Medan. The stages of this study including collecting data on attitudes, applying treatment of learning models, and collecting data on the results of shoot lay up learning in basketball games. Implementation of the learning model treatment by direct learning and problem solving. The time for applying the treatment of the learning model (direct learning and problem solving) was carried out for 4 weeks. With the time of the study as many as 4 meetings. The study was conducted using the experimental method. This study was to compare two different learning models, namely the direct learning model and problem solving with attitude attribute variables of students, which consisted of high attitude and low attitudes.
\end{abstract}

Keywords: Learning models, attitudes, basketball

\section{Introduction}

Physical education is one of the subjects in school which is a driving force for the development of motor skills, physical abilities, knowledge, sportsmanship, habituation of healthy lifestyles and character formation (mental, emotional, spiritual and social) in order to achieve the goals of the National education system.

Physical sports and health education are one subject given at a particular school level which is one part of the overall education that prioritizes physical activity and fostering a healthy life for growth and harmonious, harmonious and balanced physical, mental, social and emotional development.

Physical education is part of a general education program that contributes, especially through motion experience, to the overall growth and development of children. Physical education is defined as education and through movement and must be carried out in appropriate ways to have meaning for the child. Physical education is a learning program that provides proportional and adequate attention to the learning domains, namely psychomotor, cognitive, and affective.

So far there has been a tendency to give meaning to the quality of education which is only associated with aspects of cognitive ability. This view has brought about the neglect of aspects of moral, morality, character, psychomotor and art. In the implementation of sports and health physical education in schools still tend to use the concept of traditional learning approaches. This means that the concept still emphasizes the mastery of basic techniques and is oriented 
towards the technical skills of playing various sports (sport-based division). The learning process does not forget the development of students' ability to understand the nature of the game itself.

The increasing of movement skills, physical fitness, knowledge, and positive attitudes towards physical education are largely determined by a good curriculum. The curriculum itself seems too abstraction to be concretely and clearly defined because in the curriculum includes everything planned and applied by the teachers, both implicitly and explicitly. One of the materials included in the physical education curriculum is basketball which is included in the big ball category.

Basketball sports were first introduced in the United States in 1891 from a physical training school (Youth Men's Christian Association). Initially basketball was intended as a recreational activity, with few rules and regulations. A century later the sport has been played and enjoyed by people throughout the world. Basketball is a sports game played by 2 teams. Each team consists of 5 players and each tries to put the ball into the basket to score and prevent the opponent from scoring.

According to Imam [1] Basketball sports is a game of sports that uses large balls, played by hand. The ball can be passed, thrown to a friend, or may be reflected on the floor in place or while walking. The goal is to put the ball into the opponent's basket. The game is carried out by two teams, each of which consists of five players, each team tries to put the ball into the opponent's basket or make a number and keep or prevent the basket itself from entering the ball. In basketball games the ball is pushed over, shifted, thrown, rolled, reflected or dribbled in all directions according to the rules or provisions of the International Basketball Ball Association (FIBA) Federation. Basketball games are complex games that consist of combining elements of motion that are well coordinated.

One interesting side of basketball games is the shoot up technique. Technically Shoot lay- up is one of the basic techniques of basketball games that must be mastered by a basketball player. Seen when a player is in a playing field, they often do lay-up techniques. Lay-up shots are alternative shots that are often used by basketball players to get as many scores as possible, these shots tend to be more effective in breaking through the opponent's defense.

There are several techniques used to insert balls into baskets, including lay shoot techniques. In this study the basic technique used was the lay up shoot. Lay up shoot is a shot that is preceded by a two-step movement accompanied by a continued movement of placing the ball into the ring [1]. According to [2] a lay up shoot shot is a shot that is done close to the basket after dribbling the ball. The circuit includes the movement of holding the ball, running or stepping forward, jumping and firing at the opponent's ring to score.

Techniques are not as easy as they seem. Many students are often confused when combining footwork and firing shots at the opponent's ring. Even though one technique produces a lot of numbers when a team does a fast break. Nowadays lay-up shoots are increasingly varied, the elements that need to be considered in lay-up shoot techniques are several types, including footsteps, hand-out and jumps. To master this technique, routine training and hard work are needed. Students are accustomed to starting by training the movement towards the opponent's basketball hoop without dribbling.

Once you are good at managing footwork, continue moving while dribbling the ball. Don't forget, practice the ability of both hands to practice this technique. Due to the difficult technique students are required to master the lay up shoot technique through physical education at school. Physical education has complex or comprehensive nature, not only focused on psychomotor learning (skills), but also includes several aspects such as, affective 
aspects (attitudes) and cognitive aspects (knowledge). With physical education, children are directed to learn from these three aspects, so that in the learning process the child gets results. It is expected that behavioral changes will occur, not only physically but also intellectually, emotionally and morally in physical education learning.

However, the reality of the lay up shoot in the field of basketball games has not matched the objectives of the learning objectives in grade XI students of SMK Raksana 2 Medan. Where in several observations carried out that there were several problems including: In grade XI of SMK Raksana 2 Medan where there were more girls than boys, and this was a problem that really appeared in physical education learning. Where female students showed lower motivation in learning physical education, this was seen when students did change clothes, line up, warm up and the material delivered.

The implementation of lay-up shoot material on basketball games was also not well implemented. This was because the facilities and infrastructure were limited, then the learning concept was indeed less attractive, as well as the use of methods / models / strategies / learning styles that were still considered monotonous in physical education learning.

When students did a lay-up shoot, where the movement of the lay-up shoot was still a problem where students' cognitive reasoning about the lay-up shoot movement was still very minimal.

If analyzed during basketball lay-up shoot learning, the teacher did not stimulate students' cognitive. So the teacher only focused on psychomotor and results. While other things like cognitive and affective were ignored. This was seen from the lack of teachers providing knowledge and stimulus on how to process the lay up shoot scientifically.

The value of mid even semester of 2017/2018 academic years showed that many students who did not pass the Minimum Score Criteria (KKM) on Basic Competence (KD) 3 were the game of lay up shoot material. And this reinforced the problem that would be raised by the researcher.

The above problem was a concrete matter that was obtained by researchers through observation / observation for $3 \mathrm{x}$. Based on the above problems, the researcher conducted treatment 2 learning models namely direct learning model (direct instruction) and problem solving.

The direct learning model is a learning model that emphasizes mastery of concepts and / or behavioral changes by prioritizing a deductive approach, with the following characteristics: (1) direct transformation and skills; (2) specific goal-oriented learning; (3) structured learning material; (4) a structured learning environment; and (5) structured by the teacher. The teacher acts as the conveyor of information, and in this case the teacher used a variety of appropriate media, such as films, tape recorder, picture, demonstration, and so on. Information conveyed can be in the form of procedural knowledge (i.e. knowledge of how to do something) or declarative knowledge, (ie knowledge of something can be facts, concepts, principles, or generalizations). Critics of using this model include that this model cannot be used at all times and not for all learning purposes and all students.

Direct learning model or direct instruction, also known as the term expository and learning strategies whole class teaching. Direct learning is a learning model consisting of teacher explanations about new concepts or skills for students. According to Arends [3] a learning model specifically designed to support student learning processes related to declarative knowledge and well-structured procedural knowledge, can be taught with a pattern of activities that are step by step step by step. 
The method of problem solving was the use of methods in learning activities by training students to deal with various problems both personal and individual problems or group problems to solve themselves or together.

Problem solving is the process of accepting challenges and efforts to solve them until they find a solution. according to [4] that the problem solving method was not only a method of teaching but also a method of thinking, because in problem solving can use other methods starting from looking for data to drawing conclusions.

The problem-solving method is a way of presenting lesson material by making the problem a starting point for discussion to be analyzed and synthesized in an effort to find solutions or answers by students. In line with the opinion above states that in the method of problem solving, subject matter is not limited to books but also comes from certain events in accordance with the applicable curriculum.

In the learning process not only related to the learning model or strategy, but psychological learning is quite influential in the learning process. For example, attitude. Attitude is the tendency of individual behavior patterns to do things in a certain way towards people, objects or ideas. Attitudes can be interpreted as a group of beliefs and feelings attached to a particular object and a tendency to act on the object in a certain way.

According to [5] "The attitude is a way of reacting to a stimulus, a tendency to react in a certain way to a stimulus or situation faced". According to [6] "Attitude is an internal symptom that has affective dimensions in the form of a tendency to react or respond in a relatively fixed way to the object of the person, both positively and negatively".

Based on several opinions above, it can be concluded that attitudes are a tendency to react and respond in a relatively fixed way to certain objects both positively and negatively. A positive attitude will give positive results to the activities carried out related to that attitude, whereas negative attitudes will have a negative impact on the results achieved from these activities.

The attitude according to [7] is an idea or feeling that someone might have about something as a result of past experience or as a result of imaginative likes and dislikes. Moreover, attitudes can change as often as we sometimes hear that a woman can change her mind. In physical education, we are concerned with students' attitudes towards physical education activity programs as well as individual activities in the program.

Based on the description of the problem above, the researcher conducted a study entitled "The Effect of Direct Learning Model, Problem Solving, and Attitude on Lay Up Shoot Learning Outcomes in Basketball Games for grade XI Students of SMK Raksana 2 Medan".

\section{Methodology}

The study was conducted using the experimental method. The experimental method was the research method used to look for the effect of certain treatments [8]. In this study was to compare two different learning models, namely the direct learning model and problem solving with attitudes of students as attribute variables which consisted of high attitude and low attitudes. 


\section{Result and Discussion}

The research design used was by level 2 × 2 with three research variables, namely one dependent variable and two independent variables. As the dependent variable was the result of learning the lay-up shoot the basketball game and two independent variables were a learning model and students' attitudes.

Learning treatment variables were divided into two, namely the direct learning model (A1) and problem solving (A2). The variables that influence namely high attitudes (B1) and low attitudes (B2).

This research was conducted at SMK Raksana 2 Medan. The stages of this study including collecting data on attitudes, applying treatment of learning models, and collecting data on the results of lay up shoot in basketball games. Implementation of the learning model treatment (direct learning and problem solving). The time for applying the treatment of the learning model (direct learning and problem solving) was carried out for 4 weeks. With the time of the study as many as 4 meetings. The results were based on the sample in Table 1 .

Table 1. Grouping Experimental Samples

\begin{tabular}{crr}
\hline $\begin{array}{l}\text { Learning } \\
\text { Model (A)/ } \\
\text { Attitude (B) }\end{array}$ & $\begin{array}{l}\text { Direct } \\
\text { Learning } \\
\text { (A1) }\end{array}$ & $\begin{array}{l}\text { Problem } \\
\text { Solving } \\
\text { (A2) }\end{array}$ \\
\hline High (B1) & 10 & 10 \\
Low (B2) & 10 & 10 \\
Total & 20 & 20 \\
\hline
\end{tabular}

The treatment in this study was using model as the independent variable was the direct learning model and problem solving, and attitudes as independent variables moderator. Before the teacher / team taught lay up shoot material on basketball learning in each treatment class, the researcher first gave signs to the teacher / team relating to the steps taken in the implementation of teaching and learning.

The conditions created for these two treatment groups were tried equally, except using the learning model. The same treatment included competency standards, material, time (number of face to face) and semester. Giving treatment to the two groups mentioned above.

Based on the results of analysis of variance at the level of $\alpha=0.05$ then obtained $\mathrm{Fh}>\mathrm{Ft}$ which was $5>4.04$. So that overall conclusions can be drawn that there were differences in lay up shoot learning outcomes in basketball games between direct learning and problem solving models.

Then proceed with the tukey test in groups A1 and A2 where $\mathrm{Qh}=4.5$ and $\mathrm{Q} t=3.79$ and based on these results it can be concluded that there were differences in the results of lay up shoot learning in basketball games between direct learning models and problem solving.

While the second hypothesis testing showed an interaction. Based on the results of the analysis of variance at the level of $\alpha=0.05$ it was obtained $\mathrm{Fh}>\mathrm{Ft}$ which was $13.88>4.06$. So, it can be concluded overall that were the interaction between learning model with attitude towards lay up shoot learning outcomes in the game of basketball. This meant that this research was going well because there were interactions. 


\section{Conclusion}

a. There are differences in lay up shoot learning outcomes in basketball games between direct learning and problem-solving models.

b. There is no interaction between learning model with attitudes toward lay up shoot learning outcomes in the game of basketball.

c. Students are taught problem solving with high attitudes better than students taught by direct learning model with low attitudes.

d. Students are taught with direct learning models with low attitudes better than students taught with problem solving with low attitudes.

\section{References}

[1] I. Sodikun, Olahraga Pilihan Bola Basket. Jakarta: Departemen Pendidikan dan Kebudayaan, 1992.

[2] H. Wissel, Bola Basket Dilengkapi Dengan Program Pemahiran Tehnik dan Taktik. Jakarta: PT. Raja Grafindo Persada, 2000.

[3] Trianto, Mendesain Model Pembelajaran Inovatif-Progresif. Jakarta: Kencana Prenada Media Grup, 2009.

[4] Z. Djamarah, Strategi Belajar Mengajar. Jakarta: Rineka Cipta, 2006.

[5] M. N. Purwanto, Psikologi Pendidikan. Bandung: Remaja Rosdakarya, 2007.

[6] M. Syah, Psikologi Pendidikan dengan Pendekatan Baru. Bandung: PT. Remaja Rosdakarya Offset, 2010.

[7] J. K. Johnson, Barry L., \& Nelson, Practical Measurement For Evaluation Physical Educaton, 3rd ed. USA: Burgess Publishing Company, 1979.

[8] Sugiyono, Metode Penelitian Pendidikan Pendekatan Kuantitatif, Kualitatif, dan $R \& D$. Bandung: Alfabeta, 2009. 